\title{
The word-superiority effect and phonological recoding
}

\author{
LESTER E. KRUEGER \\ Ohio State University, Columbus, Ohio
}

\begin{abstract}
Previous work indicates that the locus of the word-superiority effect in letter detection is nonvisual and that letter names, but not letter shapes, are more accessible in words than in nonwords, that is, scrambled collections of letters (e.g., Krueger \& Shapiro, 1979; Krueger \& Stadtlander, 1991; Massaro, 1979). The nonvisual (verbal or lexical) coding may be phonological, or it may be more abstract. In the present study, a word advantage in the speed of letter detection was found even when the target letter was silent in the six-letter test word (e.g., $s$ in ISLAND). Other test words varied in their frequency of occurrence in English and number of syllables (1, 2 , or 3). The word advantage was larger for higher frequency words but was not affected by syllable length. The presence of unpronounceable nonwords and silent letters in the words discouraged reliance upon the phonological code but did not thereby eliminate the word advantage. Thus, the word-superiority effect with free viewing is not based entirely upon phonological recoding.
\end{abstract}

Letter detection typically is faster and/or more accurate in a word than in a nonword, that is, a scrambled collection of letters (Henderson, 1975; Krueger, 1975a). The word advantage involves a nonvisual (verbal or lexical) rather than a visual-spatial code (Krueger, 1975b; Krueger \& Shapiro, 1979; Krueger \& Stadtlander, 1991; Massaro, 1979; Thompson \& Massaro, 1973). The nonvisual representation of the word may be speech related (Van Orden, Pennington, \& Stone, 1990), or it may be more abstract (Prinzmetal, Hoffman, \& Vest, 1991), obtained directly from the visual input based upon orthographic or spelling regularities (Baron \& Thurston, 1973; Prinzmetal, Treiman, \& Rho, 1986; Singer, 1980). According to dual-access models, phonological and visual mediation ordinarily are used in parallel (McCusker, Hillinger, \& Bias, 1981; see also Venezky \& Massaro, 1987).

Many factors, including task, affect which type of mediation (phonological, visual) predominates in a given case (Gielen, Brysbaert, \& Dhondt, 1991; McCusker et al., 1981), and the contribution of phonological recoding to the word advantage in letter detection may depend in part upon the experimental methodology (backward masking, free viewing) used. There may, in fact, be several different word advantages in letter detection, some or all of which may depend upon phonological recoding. The word advantage in letter detection is manifested both in response time (RT), as in the free-viewing, letter-search procedure (Krueger, 1970b) that is used in the present study, and in errors, as in Reicher's (1969) backward-masking, two-

The author is grateful to Alice F. Healy, Dominic W. Massaro, Margaret J. Intons-Peterson, and Leann $M$. Stadtlander for helpful comments on an earlier version of this report. Requests for reprints should be sent to L. E. Krueger, Department of Psychology, 1885 Neil Avenue Mall, Columbus, OH 43210-1222 (e-mail: ts0340@ohstmvsa.acs.ohiostate.edu). alternative forced-choice procedure, for example, $D$ and $\mathrm{K}$ are presented along with a mask after the test word, MILK.

\section{Backward-Masking Studies}

Using the Reicher procedure, Spoehr and Smith (1973, Experiment III) found that a higher proportion of individual letters were correctly reported in one-syllable than in two-syllable words. Spoehr (1978, Experiment III) obtained the syllable-length effect even when the number of phonemes in the one-syllable and two-syllable words was equated and also found that accuracy was higher on one-syllable words that contained four rather than five phonemes (see also Chastain, 1987, Experiment 3). With the Reicher procedure, the effective stimulus duration is controlled with a postexposure mask; when the mask was eliminated, so was the word-superiority effect (Johnston, 1981; Johnston \& McClelland, 1973), and so, too, were the syllable-length and phoneme-length effects (Spoehr, 1978, Experiment III). The phonological-length effects also vanished when the delay of the mask was greatly reduced, so that the mask and the letter alternatives arrived only .1 sec or less after the stimulus array (Spoehr, 1978). Spoehr (1978) concluded that the mask, by removing visual information, "forces responses to be based on phonological recoding whenever time constraints allow such a code to be completed" (p. 140).

In the Reicher task, phonological recoding may be used primarily to bolster short-term memory rather than to achieve word identification (Banks, Oka, \& Shugarman, 1981; Shulman, Hornak, \& Sanders, 1978). Chastain (1981) found a phonological effect when the target letters (vowels) were precued rather than postcued, and thus the memory factor was minimized. He added a fourth, terminal letter along with the postexposure mask and found that the word advantage was smaller when the added 
letter changed the pronunciation of the target vowel (e.g., A in BANE) than when it did not (e.g., A in BAND). However, the added letter may have changed the orthographic structure of the item (Massaro, 1979; Massaro, Venezky, \& Taylor, 1979) in addition to the pronunciation of the target vowel, making the item less English-like in its letter sequences (bigrams, etc.).

Other research indicates that the word advantage on errors with the Reicher procedure does not depend upon phonological recoding (Baron \& Thurston, 1973; Hawkins, Reicher, Rogers, \& Peterson, 1976). Hawkins et al. presented words and single letters as stimuli and used pairs of words or letters as response alternatives. The word advantage was reduced or eliminated on homophonic alternatives (e.g., SENT/CENT) that occurred infrequently. When the proportion of homophones was high, the word advantage was as large for the homophonic pairs as for the nonhomophonic pairs (e.g., sold/COLD) (see also Baron \& Thurston, 1973). Hawkins et al. concluded that while phonetic information often may aid "the processing of tachistoscopically presented word stimuli, such information is not necessary for the maintenance of the superiority of words over single-letter stimuli"' (p. 384).

\section{Free-Viewing Studies}

Phonological recoding sometimes occurs during freeviewing visual search. Krueger (1970a) found faster and more accurate search through background letters that did not sound similar to the target letter. The effect depended upon sound rather than a more abstract letter-name code (cf. Henderson, 1973) because it was greater for high subvocalizers of the target letter. Read (1983) obtained evidence that readers have difficulty detecting the letter $F$ in of because they scan acoustic rather than visual images of the printed word, thus detecting the sound $/ \mathrm{v} /$ instead of /f/ (see also Goldman \& Healy, 1985).

Some evidence suggests that the word advantage in the speed of letter detection depends upon phonological recoding. Krueger's (1970b) subjects reported that they subvocalized some words, searching for the sound rather than the shape of the target letter, and encountered problems with silent letters (e.g., $s$ in ISLAND) and irregular pronunciations (e.g., G in COLLEGE). Krueger and Shapiro's (1979, Experiment 3A) three well-practiced subjects likewise agreed that silent letters (e.g., $H$ in SLIGHT, $E$ in CLOTHE) seemed quite difficult to detect in words.

Silent letters are often missed in words embedded in a prose context (Corcoran, 1966, 1967; Corcoran \& Weening, 1968). Drewnowski and Healy (1982) found no effects of letter voicing (silent vs. pronounced) in a search for target $e$ in a printed prose passage, however, when various factors (e.g., word class, word frequency, location of target letter in word) were controlled. They found more errors on es occurring in unstressed syllables than in stressed syllables under certain conditions, and they concluded that "subjects looking for target letters scan a phonetically recoded version of text," but "the phonetic units scanned do not appear to be at the letter level, but rather at the level of the syllable" (p. 154).

\section{The Present Study}

Two phonological factors, one at the syllable level (syllable length of 1,2 , or 3 ) and the other at the letter level (presence of silent letters), were manipulated in words. If the word advantage on RT depends upon phonological recoding, particularly that at the syllable level (Drewnowski \& Healy, 1982), then Spoehr's (1978) syllablelength effect ought to be obtained here as well, and the time savings for words should decline with syllable length. (Although phoneme length of words was not controlled, it generally increased with syllable length, so it should reinforce the effect of syllable length.)

Finding a syllable-length effect would not provide decisive evidence for the phonological factor, however. Syllables provide useful segments for the visual parsing of words (Prinzmetal et al., 1986), and thus the potential difficulty in visual parsing increases with syllable length (Banks et al., 1981). Also, words with more syllables might have less orthographic structure (Massaro, 1979; Massaro et al., 1979). A more direct test of the phonological factor was obtained by testing search for silent letters in words (e.g., the $s$ in ISLAND). If the word advantage on RT with free viewing depends upon phonological recoding, particularly that at the letter level (but see Drewnowski \& Healy, 1982), then it should be reduced or eliminated when the target letter is a silent letter in a word.

Reliance upon phonological recoding was discouraged in the present study by the presence of unpronounceable nonwords and silent letters in the words (see Hawkins et al., 1976, high-proportion homophone condition). The word advantage on RT is reduced, but not eliminated, when word and unpronounceable nonword displays are intermixed (Krueger, 1970c), which suggests that the word advantage on RT is not based entirely upon phonological recoding and that it will persist even under the present conditions.

\section{EXPERIMENTS 1, 2, AND 3}

The target letter was designated before (Experiments 1 and 2) or after (Experiment 3) the word or nonword was presented. Postcuing of the target letter was used in Experiment 3 in order to increase the opportunity for finding a phonological effect. Words may be phonetically coded in short-term memory, even if phonetic mediation is not used for the initial identification of the words (Banks et al., 1981; Humphreys \& Evett, 1985; Shulman et al., 1978).

In all three experiments, the $\mathbf{4 5}$ words in Set 1 (listed in Appendix A) each contained a silent letter in the position tested on positive (target-present) trials. The 45 words in Set 2 (listed in Appendix B) contained a pronounced letter in the same position, and each was matched as 
closely as possible with the corresponding silent-letter word in Set 1 as to the identity of the letter in that position and word frequency in English (see Appendixes A and B). Because the word frequency in English was generally quite low, only a small-to-modest word advantage on RT was expected for Sets 1 and 2. Any decrease or reversal in the word advantage on RT in Set 1, as compared with Set 2, would reflect the disruptive effect of the silent letter.

In Experiment 1, the silent letter in all $\mathbf{4 5}$ words in Set 1 matched the target letter, which may have prompted subjects to direct special attention to the silent-letter position. Therefore, in Experiments 2 and 3, only half of the 45 words in Set 1 were tested at the silent-letter position, the remaining half being "no"' (target-absent) trials. Thus, the presence of a silent letter would no longer be a highprobability clue that the correct response was "yes" (target present). To further conceal the purpose of the silentletter words, the words of Sets 1 and 2 were intermixed with the words of Sets 3 and 4 , which generally contained only pronounceable letters (see Appendixes $C$ and $D$ ) and which varied in frequency in English and syllable length $(1,2,3)$. A larger word advantage on $\mathbf{R T}$ was expected for the higher frequency Set 3 than the lower frequency Set 4 (Krueger, 1970b).

\section{Method}

Subjects. Sixty-six Ohio State University undergraduates participated for credit in an introductory psychology course, with 22 each serving in Experiments 1, 2, and 3. Data were excluded on 10 additional subjects ( 2 in Experiment 1; 4 each in Experiments 2 and 3 ) whose errors exceeded $8 \%$ and on 1 subject (Experiment 2) who failed to follow the instructions. All subjects had at least 20/30 vision (corrected) as tested with a Snellen chart.

Apparatus. Uppercase letters were presented at a $60-\mathrm{Hz}$ refresh rate and at $32 \mathrm{~cd} / \mathrm{m}^{2}$ intensity on a greenish-tint, fast-decay P31 phosphor (decay to $1 \%$ intensity at $.25 \mathrm{msec}$ after display offset) by an Imlac PDS-4 graphics computer, which measured RT to an accuracy of $1 \mathrm{msec}$. The letters, presented as thin, illuminated lines on a dark screen, were software generated, using short line vectors, so as to resemble normal English uppercase letters. Each letter was $.29 \mathrm{~cm}$ wide $\times .43 \mathrm{~cm}$ high, and $.19 \mathrm{~cm}$ separated adja-

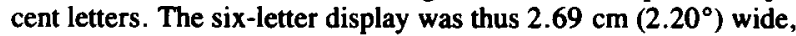
and it was centered $3 \mathrm{~mm}$ above a small $(1.6 \times 1.6 \mathrm{~mm})$ plus sign, which was the fixation mark at the center of the screen. Each subject sat alone in a dark room, with the head held fast in a chinrest located $70 \mathrm{~cm}$ from the display screen.

Stimulus materials. Each word contained six different letters and was presented once to each subject. Two word sets (Sets 1 and 2) were devised to test the effect of silent letters, and the other two sets (Sets 3 and 4 ) to test the effect of syllable length $(1,2,3)$ and frequency in English. In Appendixes A, B, C, and D, which list the four sets of words, the frequency of occurrence per million words of printed English (Kucera \& Francis, 1967) is shown beside each word, and the mean phoneme length for each column is shown in the bottom row.

The 90 words in Sets 1 and 2 are listed in Appendixes A and $B$ by position tested on positive (target-present) trials. Some silentletter words were obtained for Set 1 from Hanna, Hanna, Hodges, and Rudorf (1966), who list words for each letter combination, for example, $k n$, representing a particular phoneme, for example, $/ \mathbf{n} /$. To minimize practice and set effects, no more than two instances of each letter combination were used at a given position (e.g., walker, talked at Position 3, castle, hustle at Position 4; see Appendix A). To form Set 2, a corresponding word was obtained for each silent-letter word in Set 1 . That word had a pronounced consonant in the silent letter's position (the same letter, if possible) and had approximately the same frequency in English. Mean phoneme length was generally shorter by about one phoneme at each position for Set 1 than for Set 2 (see bottom rows of Appendixes $A$ and $B$ ), as would be expected, considering that each word in Set 1 contained a silent letter.

Sets 3 and 4 were devised by matching particular three-syllable six-letter words, which are relatively rare, with one-syllable and two-syllable words having approximately the same frequency of occurrence in English. Two students checked the syllable lengths assigned, and a dictionary was also used to verify some lengths. Mean phoneme length was $4.77,5.52$, and 5.95 , respectively, for words of 1,2 , and 3 syllables. The words were divided in half to form a higher frequency Set 3 (Appendix C) and a lower frequency Set 4 (Appendix D).

In addition to the 270 words (45 each in Sets 1 and 2; 90 each in Sets 3 and 4), there were 270 corresponding nonwords. For each column of words in Appendixes A, B, C, and D, a set of nonwords was devised by randomly permuting the letters within each of the six letter positions, with the constraint that no real words be formed and that no letter be repeated within a nonword. For Sets 1 and 2, the same set of target letters was tested at each position on positive trials for nonwords as for words. Nonwords generally were unpronounceable, except as sets of individual letters, and thus the syllable-length and silent-versus-pronounced-letter factors pertain only to words. The nonwords provided a control for visual features. Words were compared against the corresponding sets of nonwords, which contained the same visual features as the words. Words in both Sets 1 and 2 excelled over the corresponding nonwords in terms of the familiarity of the abstract code, but only words in Set 2 excelled over the nonwords in terms of target-letter pronounceability. Thus, if the subjects relied upon phonological recoding for words, a word advantage would be found for Set 2, but not for Set 1 .

In Experiment 1, all words in Sets 1 and 2, and the corresponding nonwords, were shown on "yes" (target-present) trials, with the target being the letter in the position designated (i.e., column number in Appendix A or B). In Experiments 2 and 3, however, half of the trials for Sets 1 and 2 were "no" (target-absent) trials; the even-numbered members (i.e., HOURLY, GNOMES, ... APLOMB in Appendix A) of each set of words or nonwords were assigned to "no" for half of the subjects, and the odd-numbered members (i.e., HONEST, GNAWED, ... DEBRIS in Appendix A) to "no" for the other half of the subjects. On "no" trials, a target letter that did not appear in the test item was randomly drawn from one of the other items in the same column. For Sets 3 and 4, each column of 30 words or nonwords had 12 members assigned to "no" (targetabsent) trials and 18 members ( 3 for each of the six letter positions) to "yes" (target-present) trials.

The 540 ( 270 word, 270 nonword) trials were randomly intermixed and formed into 18 blocks of 30 trials each. There were 396 "yes" and 144 "no" trials in Experiment 1 and 306 "yes" and 234 "no" trials in Experiments 2 and 3. Two practice trials preceded each block, and there was a practice block of 18 trials, for a total of 594 trials (540 regular, 54 practice). An additional set of 30 words and 30 corresponding nonwords was devised to provide items for the 54 practice trials. Four different random orderings of trials and target letters were used in Experiment 1 and another four in Experiments 2 and 3.

Procedure. On each trial, the fixation mark appeared alone for $.5 \mathrm{sec}$. In Experiments 1 and 2, the target letter then appeared in the second letter position of the upcoming item for $1 \mathrm{sec}$, followed by the fixation mark alone for $.5 \mathrm{sec}$. The word or nonword then appeared just above the fixation mark until a response was made. In Experiment 3, the sequence was reversed; the word or nonword 
appeared for $2 \mathrm{sec}$, followed by the fixation mark alone for $.5 \mathrm{sec}$, and then the target letter. No feedback was given on response accuracy during the .3-sec interval between trials. During the 10-sec interval between blocks, the next series of trials was read in from the host computer.

The subjects were instructed to respond as rapidly as possible without sacrificing accuracy. Half of the subjects pressed a righthand button if the target letter was present and a left-hand button if it was absent; the other half had the reverse hand assignment. Trials with an RT greater than $3 \mathrm{sec}$ or less than $200 \mathrm{msec}$ were discarded prior to data analysis. Mean RT was computed for correct trials only. I report the standard error $(S E)$ of the difference for factors having two levels and the mean square error $\left(M S_{\mathrm{e}}\right)$ term for factors having more than two levels.

\section{Results and Discussion}

The detectability of silent versus pronounced letters (Sets 1 and 2) is examined first, followed by the effects of syllable length and word frequency in English (Sets 3 and 4).

Detectability of silent versus pronounced letters in words (Sets 1 and 2). Data will be examined first for Experiment 1 (all "yes" trials) and then jointly for Experiments 2 and 3 (half "yes" and half "no" trials). In Experiment 1, the main analysis examined the effect of the lexicality (word vs. nonword) of the display and the sound (silent vs. pronounced) of the target letter in the word. As shown in Table 1, there was a significant word advantage on RT $[F(1,21)=18.51, p<.001, S E=$ $6.76]$ but not on errors $[F(1,21)=2.22$, n.s. $]$. The word advantage on RT was much larger in the silent-letter condition, reflecting a significant lexicality $\times$ sound interaction on RT $[F(1,21)=22.63, p<.001, S E=5.13]$. In separate analyses, the word advantage on RT was significant for Set 1 (silent-letter word condition) $[F(1,21)$ $=30.91, p<.001, S E=9.62]$ but not for Set 2 (pronounced-letter word condition) $(F<1)$.

In Experiments 2 and 3, the main analysis examined the effect of precuing (Experiment 2) versus postcuing (Experiment 3 ) the target letter, target presence, lexicality, and sound (silent vs. pronounced) of the target letter in the word. As shown in Table 1, RT was significantly faster on target-present trials $[F(1,42)=115.25, p<$

Table 1

Set 1 Versus Set 2: Mean Response Time (RT) in Milliseconds and Percentage of Error (PE) Rate by Lexicality and Target Presence

\begin{tabular}{|c|c|c|c|c|c|c|c|c|}
\hline \multirow[b]{3}{*}{ Set } & \multicolumn{4}{|c|}{ Target Present } & \multicolumn{4}{|c|}{ Target Absent } \\
\hline & \multicolumn{2}{|c|}{ Words } & \multicolumn{2}{|c|}{ Nonwords } & \multicolumn{2}{|c|}{ Words } & \multicolumn{2}{|c|}{ Nonwords } \\
\hline & RT & PE & RT & PE & RT & $\mathrm{PE}$ & RT & $\mathbf{P E}$ \\
\hline \multicolumn{9}{|c|}{ Experiment 1} \\
\hline 1 & $\begin{array}{l}596 \\
636\end{array}$ & $\begin{array}{l}2.77 \\
3.69\end{array}$ & 650 & $\begin{array}{l}3.49 \\
487\end{array}$ & - & - & - & - \\
\hline \multicolumn{9}{|c|}{ Experiment 2} \\
\hline 1 & 700 & 3.81 & 761 & 5.40 & 837 & 3.07 & 872 & 2.45 \\
\hline 2 & 726 & 5.04 & 738 & 7.29 & 825 & 3.26 & 832 & 2.24 \\
\hline \multicolumn{9}{|c|}{ Experiment 3} \\
\hline 1 & 704 & 7.06 & 758 & 8.59 & 876 & 2.26 & 920 & 4.23 \\
\hline 2 & 742 & 4.26 & 754 & 6.14 & 903 & 3.84 & 920 & 2.03 \\
\hline
\end{tabular}

Table 2

Set 1 Versus Set 2: Mean Response Time (RT) in Milliseconds and Percentage of Error (PE) Rate by Lexicality and Serial Position of Target Letter in Item (Target-Present Trials Only)

\begin{tabular}{|c|c|c|c|c|c|c|c|c|}
\hline \multirow{3}{*}{$\begin{array}{l}\text { Target } \\
\text { Position }\end{array}$} & \multicolumn{4}{|c|}{ Set 1} & \multicolumn{4}{|c|}{ Set 2} \\
\hline & \multicolumn{2}{|c|}{ Words } & \multicolumn{2}{|c|}{ Nonwords } & \multicolumn{2}{|c|}{ Words } & \multicolumn{2}{|c|}{ Nonwords } \\
\hline & RT & $\mathrm{PE}$ & RT & $\mathrm{PE}$ & RT & $\mathrm{PE}$ & RT & PE \\
\hline \multicolumn{9}{|c|}{ Experiment 1} \\
\hline 1 & 578 & 2.27 & 592 & 2.73 & 571 & 3.64 & 579 & 5.45 \\
\hline 2 & 619 & 1.52 & 676 & 3.79 & 655 & 2.27 & 689 & 8.33 \\
\hline 3 & 568 & 1.70 & 643 & 5.11 & 613 & 2.27 & 611 & 1.14 \\
\hline 4 & 572 & 2.84 & 620 & 1.70 & 623 & 3.98 & 622 & 2.84 \\
\hline 5 & 646 & 4.63 & 696 & 3.98 & 640 & 4.55 & 668 & 2.35 \\
\hline 6 & 594 & 3.64 & 671 & 3.64 & 714 & 5.45 & 673 & 9.09 \\
\hline \multicolumn{9}{|c|}{ Experiment 2} \\
\hline 1 & 617 & 5.45 & 663 & 3.64 & 660 & 1.82 & 682 & 5.45 \\
\hline 2 & 716 & 6.06 & 870 & 10.61 & 808 & 9.09 & 795 & 7.58 \\
\hline 3 & 666 & 4.55 & 730 & 1.14 & 651 & 1.14 & 716 & 4.92 \\
\hline 4 & 708 & 1.14 & 688 & 4.55 & 731 & 2.27 & 644 & 4.55 \\
\hline 5 & 758 & 5.68 & 836 & 7.95 & 816 & 4.55 & 803 & 4.55 \\
\hline 6 & 732 & 0.00 & 777 & 4.55 & 687 & 11.36 & 789 & 16.67 \\
\hline \multicolumn{9}{|c|}{ Experiment 3} \\
\hline 1 & 663 & 6.36 & 690 & 9.09 & 642 & 0.91 & 671 & 7.27 \\
\hline 2 & 755 & 15.15 & 774 & 13.64 & 758 & 6.06 & 813 & 4.54 \\
\hline 3 & 681 & 3.41 & 807 & 7.95 & 725 & 1.14 & 709 & 5.68 \\
\hline 4 & 715 & 3.41 & 685 & 6.82 & 758 & 3.41 & 732 & 1.14 \\
\hline 5 & 701 & 7.95 & 754 & 5.68 & 798 & 5.68 & 757 & 6.82 \\
\hline 6 & 708 & 6.06 & 839 & 8.33 & 770 & 8.33 & 844 & 11.36 \\
\hline
\end{tabular}

$.001, S E=12.84]$, especially in Experiment 3 ; the Experiment 2 versus Experiment $3 \times$ target presence interaction on RT was significant $[F(1,42)=4.60, p<.05$, $S E=12.84]$. Mean RT also was significantly fáster on word trials $[F(1,42)=21.49, p<.001, S E=6.61]$, especially with a silent letter (Set 1 ); the lexicality $\times$ sound interaction was significant on RT $[F(1,42)=5.80$, $p<.025, S E=7.43]$. The latter effect and interaction did not differ by experiment ( $F<1$ in both cases). In separate analyses, the word advantage on RT was significant for the silent-letter condition $[F(1,42)=28.74$, $p<.001, S E=9.05]$ but not for the pronounced-letter condition $[F(1,42)=1.40$, n.s. $]$.

Errors in Experiments 2 and 3 were significantly higher on target-present trials $[F(1,42)=43.74, p<.001$, $S E=.457]$, especially on nonword trials; the lexicality $X$ target presence interaction on errors was significant $[F(1,42)=4.70, p<.05, S E=.503]$. The latter effect and interaction did not differ by experiment $(F<1$ in both cases). The interaction indicates that when the target letter was present, it was less likely to be missed in a word than in a nonword.

In separate analyses of target-present ("yes") trials, target position had a significant effect on RT in Experiment 1 $\left[F(5,105)=10.34, p<.001, M S_{\mathrm{e}}=10,894\right]$, and on both RT $\left[F(5,210)=20.25, p<.001, M S_{\mathrm{e}}=21,470\right]$ and errors $\left[F(5,210)=4.99, p<.001, M S_{\mathrm{e}}=196\right]$ in Experiments 2 and 3. In all three experiments, both errors and RT were lower in Positions 1, 3, and 4 than in Positions 2, 5, and 6 (see Table 2). After the session, about half of the subjects in Experiments 1 and 2 (precued 
target) said they scanned the six-letter item left to right, which is consistent with the better performance found at Position 1 (far left). In Experiment 3 (postcued target), many subjects said that they chunked the letters together in threes on nonwords, examining first the first three letters and then the second three letters. Positions 3 and 4 no doubt fared better because they were centered immediately above the fixation mark.

Enhanced word-superiority effect for silent-letter word condition (Set 1). It had been expected that the word advantage on RT for Set 2 would equal or exceed that for Set 1 . Just the opposite occurred. In fact, there was no significant word advantage on RT for Set 2, which may suggest that it did not provide an adequate comparison condition for Set 1 . This requires some discussion.

Half of the words in Sets 1 and 2 occur four or fewer times per million words in printed English. That low frequency along with the small size of Sets 1 and 2, which would tend to produce unstable RT data, may have undermined the word advantage for Set 2. As shown below, words having a frequency of 4 to 12 produced only a modest, 20-msec word advantage in Set 4 . The fact that Set 1 produced a significant word advantage, even though it suffered the same disadvantages in terms of set size and frequency, makes its results that much more impressive.

The increased word advantage on RT for Set 1 was broadly based and not simply due to an outsized word advantage at a particular serial position. On positive ("yes") trials, the enhanced word advantage for silent letters was evident at all six target-letter positions in Experiment 1 and at most target-letter positions in Experiments 2 and 3 (see Table 2 ). The target position $\times$ lexicality $\times$ sound interaction on RT for "yes" trials was nonsignificant, both in Experiment $1(F=1.68)$ and in Experiments 2 and $3(F<1)$.

Sets 1 and 2 were closely matched on word frequency in English, but it may be that silent-letter words at one frequency level had a special advantage. When words in Sets 1 and 2 were classified by six levels of word frequency $(0-1,2-4,6-8,12-25,46-71,100-888)$ in order to give equal weight to the various levels of word frequency, mean RT was significantly lower for Set 1 words than for Set 2 words in Experiment $1[F(1,14)=14.01$, $p<.01, S E=8.92]$. The latter effect interacted significantly with frequency level $[F(5,105)=2.67, p<.05$, $\left.M S_{\mathrm{e}}=5,492\right]$; the Set 1 advantage in Experiment 1 was $1,89,16,14,69$, and $11 \mathrm{msec}$, respectively, for the six frequency levels, indicating that it held at all levels except the lowest frequency level $(0-1)$. Thus, the advantage for silent-letter words again proved to be broadly based.

Might the silent-letter words in Set 1 be associated with overlearned orthography? Mean positional bigram frequency per 20,000 six-letter words was 26.44 and 32.30 , respectively, for Sets 1 and 2, whereas mean positional trigram frequency was 5.40 and 4.71 (Mayzner \& Tresselt, 1965; Mayzner, Tresselt, \& Wolin, 1965). Thus, the two sets of words were well matched on orthographic structure (Massaro, 1979; Massaro et al., 1979).

Some silent-letter patterns appeared twice in Set 1 (e.g., WALKER, TALKED), which may have facilitated processing on the second occurrence of the pattern. Such a practice or set effect, if present, most likely would have been quite small, however, given the many other words and nonwords that typically intervened between the two occurrences of such patterns, and it cannot reasonably explain the enhanced word advantage for Set 1.

The longer mean phoneme length of the words in Set 2 may have decreased the word advantage on them (Chastain, 1987; Spoehr, 1978; Spoehr \& Smith, 1973). Phoneme or syllable length had no effect on the word advantage on RT in Sets 3 and 4, however, as shown below, so it likely did not affect the difference in word advantage between Sets 1 and 2 .

Although silent-letter words were presented on only 45 of the 540 regular trials, they evidently stood out and received special processing, as the enhanced word advantage for Set 1 indicates. After the session, most subjects said "yes" when asked, "Was the target letter ever a silent letter in the word, for example, the $s$ in ISLAND?" (55\%, 55\%, and $73 \%$ "yes" responses, respectively, in Experiments 1, 2, and 3). The subjects answering "yes" indicated that this happened on $20 \%, 14 \%$, and $26 \%$, respectively, of the trials in Experiments 1, 2, and 3. (The true prevalence of positive trials for Set 1 words was $8 \%$, $4 \%$, and $4 \%$, respectively, in Experiments 1,2 , and 3, but silent letters may have been tested in Sets 3 and 4 as well.) When further asked "How did this affect your performance?" most said it did not matter, but several subjects said that it made the task more difficult $(18 \%, 18 \%$, and $41 \%$, respectively, in Experiments 1,2, and 3), which indicates that they were discouraged from relying upon a phonological code. ${ }^{1,2}$

Effect of syllable length and word frequency in English (Sets 3 and 4). The factors analyzed, besides syllable length $(1,2,3)$ in words and word frequency in English, were lexicality (word vs. nonword) and target-letter presence. Experiments 1 and 2 were analyzed jointly, since the method was identical for the two experiments on the 360 trials ( 180 word, 180 nonword) involving the syllable-length factor. In Experiments 1 and 2, as shown in Table 3, words were lower on RT $[F(1,43)=42.31$, $p<.001, S E=4.58$ ], especially on higher frequency words (Set 3) and on target-present trials; the lexicality $\times$ word frequency interaction on RT was significant $[F(1,43)=8.54, p<.01, S E=3.45]$, as was the lexicality $\times$ target presence interaction on $\mathrm{RT}[F(1,43)=$ $5.19, p<.05, S E=3.821$. The 40 -msec word advantage for Set 3 (word frequency per million: 12 to 482 ) exceeded the 20-msec word advantage for Set 4 (word frequency: 4-12), as expected (Krueger, 1970b). ${ }^{3}$

Mean RT was lower on target-present trials $[F(1,43)$ $=172.79, p<.001, S E=12.58]$, as were errors $[F(1,43)=10.82, p<.01, S E=.525]$. Syllable length 
Table 3

Set 3 Versus Set 4: Mean Response Time (RT) in Milliseconds and Percentage of Error (PE) Rate by Lexicality, Number of Syllables $(1,2,3)$ in Word, and Target Presence

\begin{tabular}{|c|c|c|c|c|c|c|c|c|c|}
\hline \multirow[b]{3}{*}{ Set } & \multirow{3}{*}{$\begin{array}{c}\text { Number of } \\
\text { Syllables }\end{array}$} & \multicolumn{4}{|c|}{ Target Present } & \multicolumn{4}{|c|}{ Target Absent } \\
\hline & & \multicolumn{2}{|c|}{ Words } & \multicolumn{2}{|c|}{ Nonwords } & \multicolumn{2}{|c|}{ Words } & \multicolumn{2}{|c|}{ Nonwords } \\
\hline & & RT & PE & RT & PE & RT & $\mathrm{PE}$ & RT & $\mathrm{PE}$ \\
\hline \multicolumn{10}{|c|}{ EXPERIMENT 1} \\
\hline & \multicolumn{9}{|c|}{ Higher Frequency } \\
\hline \multirow[t]{3}{*}{3} & 1 & 609 & 2.27 & 655 & 4.30 & 820 & 7.57 & 850 & 6.06 \\
\hline & 2 & 626 & 2.53 & 644 & 2.53 & 798 & 6.06 & 823 & 6.06 \\
\hline & 3 & 613 & 3.03 & 664 & 3.28 & 806 & 10.98 & 830 & 7.57 \\
\hline \multicolumn{10}{|c|}{ Lower Frequency } \\
\hline 4 & 1 & 602 & 3.28 & 630 & 3.28 & 815 & 6.44 & 834 & 7.20 \\
\hline & 2 & 606 & 3.54 & 615 & 2.78 & 809 & 6.44 & 839 & 5.34 \\
\hline & 3 & 608 & 2.27 & 630 & 3.03 & 844 & 7.23 & 808 & 6.44 \\
\hline \multicolumn{10}{|c|}{ EXPERIMENT 2} \\
\hline \multicolumn{10}{|c|}{ Higher Frequency } \\
\hline 3 & 1 & 697 & 4.67 & 759 & 4.55 & 830 & 3.41 & 882 & 3.79 \\
\hline & 2 & 676 & 2.53 & 742 & 4.55 & 848 & 3.41 & 864 & 2.27 \\
\hline & 3 & 692 & 1.77 & 762 & 3.03 & 834 & 4.55 & 855 & 3.55 \\
\hline \multicolumn{10}{|c|}{ Lower Frequency } \\
\hline 4 & 1 & 697 & 7.07 & 729 & 6.06 & 866 & 3.41 & 905 & 6.44 \\
\hline & 2 & 711 & 6.57 & 740 & 3.28 & 828 & 3.03 & 846 & 3.41 \\
\hline & 3 & 704 & 3.54 & 735 & 3.03 & 832 & 3.03 & 848 & 4.55 \\
\hline \multicolumn{10}{|c|}{ EXPERIMENT 3} \\
\hline \multicolumn{10}{|c|}{ Higher Frequency } \\
\hline 3 & 1 & 741 & 5.81 & 782 & 9.34 & 869 & 3.79 & 891 & 4.58 \\
\hline & 2 & 731 & 6.44 & 805 & 7.07 & 897 & 2.27 & 892 & 4.55 \\
\hline & 3 & 758 & 5.81 & 789 & 9.85 & 858 & 1.89 & 907 & 4.92 \\
\hline \multicolumn{10}{|c|}{ Lower Frequency } \\
\hline 4 & 1 & 766 & 5.56 & 789 & 8.08 & 883 & 3.79 & 919 & 4.92 \\
\hline & 2 & 794 & 7.58 & 788 & 8.59 & 864 & 3.79 & 892 & 4.54 \\
\hline & 3 & 759 & 6.57 & 775 & 10.36 & 859 & 3.79 & 932 & 3.79 \\
\hline
\end{tabular}

in words did not interact with lexicality on either RT or errors ( $F \leq 1.30$ in both cases). The word advantage on RT was 38,26 , and $25 \mathrm{msec}$, respectively, for words containing 1,2 , and 3 syllables. Thus, the present conditions (free viewing; intermixed word and unpronounceable nonword trials) eliminated the syllable effect on the word advantage (Spoehr, 1978; Spoehr \& Smith, 1973) but did not eliminate the word advantage itself. These results indicate that the word-superiority effect with free viewing does not depend upon phonological recoding at the syllable level.

In Experiment 3, where the target letter was postcued, words had an advantage on RT $[F(1,21)=9.49, p<$ $.01, S E=10.31]$ and also on errors $[F(1,21)=10.13$, $p<.01, S E=.616]$. Syllable length in words and word frequency in English did not interact with lexicality on either RT or errors ( $F<1$ in all cases). The word advantage was 30,23 , and $42 \mathrm{msec}$, respectively, on RT and $2.00 \%, 1.17 \%$, and $2.71 \%$ on errors for words containing 1, 2, and 3 syllables, and it was 28 and $35 \mathrm{msec}$, respectively, on RT and $1.54 \%$ and $2.38 \%$ on errors for lower frequency and higher frequency words. Mean RT was lower on target-present trials $[F(1,21)=57.26, p<$ $.001, S E=15.24]$, but errors were higher $[F(1,21)=$ $20.75, p<.001, S E=.813]$.

In a special joint analysis of Experiments 2 and 3, experiment (precuing vs. postcuing of target letter) had a significant main effect on errors $[F(1,42)=7.54, p<$ $.01, S E=.640]$ and interacted on errors with lexicality $[F(1,42)=5.67, p<.025, S E=.385]$ and with target presence $[F(1,42)=11.73, p<.01, S E=.470]$. Errors were higher in Experiment 3 (vs. Experiment 2), reflecting its postcuing procedure, and the increase in errors was mainly on target-present trials and on nonwords, which presumably were less well encoded than words and thus more vulnerable to memory decay. Krueger (1970c, Experiment V) likewise found a significant word advantage on errors in letter detection with postcuing but not with precuing.

\section{CONCLUSIONS}

Using variants of the Reicher (1969) procedure (i.e., precued or postcued letter alternatives, postexposure 
masking of test item), Chastain (1981) and Spoehr (1978; Spoehr \& Smith, 1973) obtained evidence that a phonological or speech-related representation was searched. Hawkins et al. (1976), however, found that the wordsuperiority effect did not depend upon phonological recoding when a high proportion of homophonic pairs were presented as response alternatives. In the present study, which used free viewing and intermixed word and unpronounceable nonword trials, no reliance upon the phonological code, either at the letter level (Sets 1 and 2) or at the syllable level (Sets 3 and 4), was evident. Silent letters were detected just as readily as pronounced letters (the speed advantage for words in Set 1 even exceeded that for words in Sets 2, 3, and 4), and syllable length did not matter, contrary to Spoehr's findings.

Phonological recoding of words is optional, and several factors (e.g., frequency of items, difficulty of items, task demands) determine its use (Gielen et al., 1991; Hawkins et al., 1976; McCusker et al., 1981; Shulman et al., 1978). The concern here is not with phonological recoding per se, but in whether the word advantage with free viewing persists even in the absence of phonological recoding. The present study, like Hawkins et al.'s (highproportion homophone condition), discouraged reliance upon the phonological code but did not thereby eliminate the word-superiority effect. Thus, the phonological code may be sufficient to produce the word-superiority effect (Spoehr, 1978; Spoehr \& Smith, 1973), but it is not necessary (Hawkins et al., 1976, and the present results).

The backward-masking (Reicher, 1969) procedure and the free-viewing procedure may be measuring different word advantages in letter detection, because the latter procedure typically produces a word advantage on RT and the former procedure a word advantage on errors. The converging evidence obtained here, which indicates that the word advantage is no more dependent on the phonological code with the free-viewing procedure (present results) than with the backward-masking procedure (Hawkins et al., 1976), suggests that the two procedures are measuring the same word advantage.

The phonological code may potentially be more important in word storage than word identification (Banks et al., 1981; Shulman et al., 1978). In Experiment 3, the target letter was postcued in order to require use of short-term memory and thus encourage phonological recoding. The presence of memory decay was indicated by the higher proportion of errors on target-present trials (i.e., misses) and on nonwords. However, even in Experiment 3, the word advantage on RT did not decrease with silent-letter targets or with increased syllable length. The presence of silent letters, as well as other irregularities in the pronunciation of the intermixed nonwords and words, evidently discouraged the subjects from relying upon a phonological code for word storage.

Most subjects had access to the phonological code, as their self-reports obtained after the session indicate, but simply chose not to rely exclusively upon it. Thus, the subjects may have coded the words both phonologically and nonphonologically, in accord with the dual-access models reviewed by McCusker et al. (1981). Mismatches detected between the nonphonological code and the phonological code may have enabled the subjects to detect the presence of silent letters and direct special attention to them. That may explain why a word advantage was found on RT for the silent-letter (Set 1) words but not for the matched pronounced-letter (Set 2) words. Alternatively, the tipoff to the presence of a silent letter may have come when the incipient phonetic coding of the letter was inhibited or suppressed once the word as a whole had been identified. In either case, however, it was the nonphonological code that ultimately was relied upon to detect the silent letter, or to verify its presence. In the phonological code, after all, the silent letter was simply a nonspecific gap or missing element.

\section{REFERENCES}

Banks, W. P., Oka, E., Shugarman, S. (1981). Recoding of printed words to internal speech: Does recoding come before lexical access? In O. J. L. Tzeng \& H. Singer (Eds.), Perception of print: Reading research in experimental psychology (pp. 137-170). Hillsdale, NJ: Erlbaum.

BARON, J., ThURSTON, I. (1973). An analysis of the word-superiority effect. Cognitive Psychology, 4, 207-228.

Chastan, G. (1981). Phonological and orthographic factors in the wordsuperiority effect. Memory \& Cognition, 9, 389-397.

ChastaIN, G. (1987). Visually-presented letter strings typically are encoded phonologically: Some converging evidence. Joumal of General Psychology, 114, 147-156.

Corcoran, D. W. J. (1966). An acoustic factor in letter cancellation. Nature, 210, 658.

Corcoran, D. W. J. (1967). Acoustic factors in proof reading. Nature, 214, 851-852.

Corcoran, D. W. J., Weening, D. L. (1968). Acoustic factors in visual search. Quarterly Joumal of Experimental Psychology, 20, 83-85.

Drewnowski, A., * Healy, A. F. (1982). Phonetic factors in letter detection: A reevaluation. Memory \& Cognition, 10, 145-154.

Gielen, I., Brysbaert, M., \& Dhondt, A. (1991). The syllable-length effect in number processing is task-dependent. Perception \& Psychophysics, 50, 449-458.

Goldman, H. B., Healy, A. F. (1985). Detection errors in a task with articulatory suppression: Phonological recoding and reading. Memory \& Cognition, 13, 463-468.

Hanna, P. R., Hanna, J. S., Hodges, R. F., Rudorf, E. H., JR. (1966). Phoneme-grapheme correspondences as cues to spelling improvement (Bureau of Research, Office of Education). Washington, DC: U.S. Government Printing Office.

hawkins, H. L., Reicher, G. M., Rogers, M., \& Peterson, L. (1976). Flexible coding in word recognition. Journal of Experimental Psychology: Human Perception \& Performance, 2, 380-385.

Henderson, L. (1973). Effects of letter-names on visual search. Cognitive Psychology, 5, 90-96.

Henderson, L. (1975). Do words conceal their component letters? A critique of Johnson (1975) on the visual perception of words. Journal of Verbal Learning \& Verbal Behavior, 14, 648-650.

HumphreYs, G. W., EveTt, L. J. (1985). Are there independent lexical and nonlexical routes in word processing? An evaluation of the dual-route theory of reading. Behavioral \& Brain Sciences, 8, 689-740.

Johnson, N. F., Allen, P. A., Strand, T. L. (1989). On the role of word frequency in the detection of component letters. Memory \& Cognition, 17, 474-482.

JoHNSTON, J. C. (1981). Effects of advance precuing of alternatives on the perception of letters alone and in words. Joumal of Experimental Psychology: Human Perception \& Performance, 7, 560-572. 
Johnston, J. C., \& MCClelland, J. L. (1973). Visual factors in word perception. Perception \& Psychophysics, 14, 365-370.

Krueger, L. E. (1970a). The effect of acoustic confusability on visual search. American Journal of Psychology, 83, 389-400.

KRUEGer, L. E. (1970b). Search time in a redundant visual display. Journal of Experimental Psychology, 83, 391-399.

KRUEGER, L. E. (1970c). Visual comparison in a redundant display Cognitive Psychology, 1, 341-357.

KrUEGER, L. E. (1975a). Familiarity effects in visual information processing. Psychological Bulletin, 82, 949-974.

KRUEGER, L. E. (1975b). The word-superiority effect: Is its locus visualspatial or verbal? Bulletin of the Psychonomic Society, 6, 465-468.

KRUEGER, L. E., \& ShapIRo, R. G. (1979). Letter detection with rapid serial visual presentation: Evidence against word superiority at feature extraction. Journal of Experimental Psychology: Human Perception \& Performance, 5, 657-673.

Krueger, L. E., \& Stadtlander, L. M. (1991). Detection of letter repetition in words and nonwords: The effect of opposite-case distractors. Journal of Experimental Psychology: Human Perception \& Performance, 17, 942-950.

KUČERA, H., \& Francis, W. N. (1967). Computational analysis of present-day American English. Providence, RI: Brown University Press.

MASSARO, D. W. (1979). Letter information and orthographic context in word perception. Joumal of Experimental Psychology: Human Perception \& Performance, 5, 595-609.

Massaro, D. W., Venezky, R. L., Taylor, G. A. (1979). Orthographic regularity, positional frequency, and visual processing of letter strings. Joumal of Experimental Psychology: General, 108, 107-124.

Mayzner, M. S., \& Tresselt, M. E. (1965). Tables of single-letter and digram frequency counts for various word-length and letter-position combinations. Psychonomic Monograph Supplements, 1, 13-32.

Mayzner, M. S., Tresselt, M. E., \& Wolin, B. R. (1965). Tables of trigram frequency counts for various word-length and letter-position combinations. Psychonomic Monograph Supplements, 1, 33-78.

McCusker, L. X., Hillinger, M. L., \& Bias, R. G. (1981). Phonological recoding and reading. Psychological Bulletin, 89, 217-245.

Prinzmetal, W., Hoffman, H., \& Vest, K. (1991). Automatic processes in word perception: An analysis from illusory conjunctions Journal of Experimental Psychology: Human Perception \& Performance, 17, 902-923.

Prinzmetal, W., Treiman, R., Rho, S. H. (1986). How to see a reading unit. Journal of Memory \& Language, 25, 461-475.

READ, J. D. (1983). Detection of Fs in a single statement: The role of phonetic recoding. Memory \& Cognition, 11, 390-399.

REICHER, G. M. (1969). Perceptual recognition as a function of meaning fulness of stimulus material. Joumal of Experimental Psychology, 81, 275-280.

Shulman, H. G., Hornak, R., \& Sanders, E. (1978). The effects of graphemic, phonetic, and semantic relationships on access to lexical structures. Memory \& Cognition, 6, 115-123.

SinGER, M. H. (1980). The primacy of visual information in the analysis of letter strings. Perception \& Psychophysics, 27, 153-162.

SPOEHR, K. T. (1978). Phonological encoding in visual word recognition. Journal of Verbal Learning \& Verbal Behavior, 17, 127-141.

SPOEHR, K. T., \& SMITH, E. E. (1973). The role of syllables in perceptual processing. Cognitive Psychology, 5, 71-89.

Thompson, M. C., \& Massaro, D. W. (1973). Visual information and redundancy in reading. Journal of Experimental Psychology, 98, 49-54.
Van Orden, G. C., Pennington, B. F., Stone, G. O. (1990). Word identification in reading and the promise of subsymbolic psycholinguistics. Psychological Review, 97, 488-522.

Venezky, R. L., MASSARo, D. W. (1987). Orthographic structure and spelling-sound regularity in reading English words. In A. Allport, D. MacKay, W. Prinz, \& E. Scheerer (Eds.), Language perception and production: Shared mechanisms in listening, speaking, reading and writing (pp. 159-179). London: Academic Press.

\section{NOTES}

1. If the subjects had relied primarily upon pronunciation until the first silent letter was tested in a word, after which they switched to another code, then RT and errors ought to be quite high on the very first "yes" trial for a word in Set 1. That did not happen. Performance was not notably worse on the initial silent-letter target word than on the nearest appearing nonword and word from another set that had target letters in the same position. Errors were virtually identical for these three trials in Experiments 1, 2, and 3. Mean RT on the silent-letter word (738 msec) surpassed that on the other word $(711 \mathrm{msec})$ but was lower than that on the nonword $(753 \mathrm{msec})$. These differences were nonsignificant on sign tests. Thus, the subjects showed little evidence of heightened surprise or disruption from their first encounter with a silent-letter target in a word in Set 1, perhaps because the nonwords generally were not pronounceable and some words in Sets 3 and 4 also contained silent letters.

2. In each experiment, the subjects were divided in half, that is, classified as low or high subvocalizers, depending on how frequently they said the target letter was a silent letter in the word $(0 \%-1 \%, 0 \%-1 \%$, and $0 \%-13 \%$, respectively, for the low subvocalizers in Experiments 1, 2 , and $3 ; 10 \%-30 \%, 5 \%-30 \%$, and $15 \%-50 \%$ for the high subvocalizers). The low versus high subvocalizers $\times$ lexicality $\times$ sound interaction was marginally significant on RT in Experiment $1[F(1,20)$ $=3.78, p<.10, S E=4.82]$ but was nonsignificant $(F<1)$ on errors in Experiment 1 and on both RT and errors in Experiments 2 and 3. In Experiment 1, the word advantage on RT was $67 \mathrm{msec}$ larger on Set 1 than on Set 2 for low subvocalizers and $29 \mathrm{msec}$ larger for high subvocalizers; in Experiments 2 and 3, it was 38 msec larger for low subvocalizers and $34 \mathrm{msec}$ larger for high subvocalizers. The fact that the enhanced Set 1 word advantage was not reliably reduced for the high subvocalizers suggests that even those subjects relied primarily upon a nonphonological code.

3. Krueger (1970b) likewise found nearly twice as large a word advantage for common words occurring $\mathbf{3 0}$ or more times per million words as for rare words occurring 1 time per million words. Johnson, Allen, and Strand (1989) found a nonmonotonic effect of word frequency, with the word advantage vanishing for words in the 175-260 frequency range. This suggests that the enhanced word advantage would not have been found if most words in the higher frequency Set 3 had fallen in the 175-260 frequency range. However, Johnson et al. had subjects compare the target letter with only the initial letter of the word or nonword, and initial letters may be processed differently than other letters in a word; for example, Drewnowski and Healy (1982) found that "the initial syllables of multisyllabic words are processed to the point of letter identification, regardless of the test word frequency or its syllabic stress pattern" (p. 154). Thus, it may be that some peculiarity of the structure or the processing of the initial letters can explain the poorer performance Johnson et al. found on words in the 175-260 frequency range. 
APPENDIX A

Set 1. Words Containing Silent Letters (Frequency of Occurrence; Kucera \& Francis, 1967) by Position of Target Letter on Positive Trials

\begin{tabular}{|c|c|c|c|c|c|c|c|c|c|c|c|}
\hline \multicolumn{2}{|c|}{1} & \multicolumn{2}{|c|}{2} & \multicolumn{2}{|c|}{3} & \multicolumn{2}{|c|}{4} & \multicolumn{2}{|c|}{5} & \multicolumn{2}{|c|}{6} \\
\hline Word & Freq. & Word & Freq. & Word & Freq. & Word & Freq. & Word & Freq. & Word & Freq \\
\hline HONEST & 47 & ISLAND & 167 & Calves & 6 & CASTLE & 7 & BEHALF & 21 & COLUMN & 71 \\
\hline HOURLY & 2 & GHOULS & 2 & DEBTOR & 0 & DOUBTS & 16 & IMPUGN & 0 & SOLEMN & 12 \\
\hline GNAWED & 1 & THOMAS & 100 & YACHTS & 3 & ANSWER & 152 & SHOULD & 888 & ENTOMB & 0 \\
\hline GNOMES & 1 & RHODES & 8 & SALMON & 3 & SOFTEN & 4 & PHLEGM & 0 & APLOMB & 1 \\
\hline KNIGHT & 18 & RHINOS & 2 & SUBTLE & 25 & QUALMS & 1 & THUMBS & 3 & DEBRIS & 8 \\
\hline KNIVES & 7 & ALMOND & 1 & WALKER & 17 & HUSTLE & 2 & DINGHY & 1 & & \\
\hline PSYCHE & 7 & & & TALKED & 58 & REIGNS & 1 & CLIMBS & 1 & & \\
\hline PSEUDO & 1 & & & TUCSON & 3 & LISTEN & 51 & DESIGN & 144 & & \\
\hline
\end{tabular}

APPENDIX B

Set 2. Words Containing Pronounced Letters (Frequency of Occurrence; Kucera \& Francis, 1967) by Position of Target Letter on Positive Trials

\begin{tabular}{|c|c|c|c|c|c|c|c|c|c|c|c|}
\hline \multicolumn{2}{|c|}{1} & \multicolumn{2}{|c|}{2} & \multicolumn{2}{|c|}{3} & \multicolumn{2}{|c|}{4} & \multicolumn{2}{|c|}{5} & \multicolumn{2}{|c|}{6} \\
\hline Word & Freq. & Word & Freq. & Word & Freq. & Word & Freq. & Word & Freq. & Word & Freq. \\
\hline HEARST & 48 & TRYING & 163 & CAPONE & 6 & CORTEX & 7 & MARBLE & 21 & CHOSEN & 71 \\
\hline HOLDUP & 2 & SHAKER & 2 & AMBLER & 1 & FLAVOR & 16 & SPONGE & 7 & SERMON & 12 \\
\hline GOTHAM & 1 & Places & 100 & NECTAR & 3 & MARKET & 155 & DURING & 585 & PREFAB & 1 \\
\hline GRAPHS & 1 & SHIELD & 8 & FOLKSY* & 3 & BIRTHS & 4 & SWINGY & 1 & MALTED & 1 \\
\hline RANGED & 18 & THORNY & 2 & PATROL & 25 & PARLEY & 1 & DANUBE & 3 & DEATHS & 8 \\
\hline KIDNEY & 6 & BLARED & 1 & MILTON & 17 & JILTED & 2 & TOUCHY & 1 & & \\
\hline POSTAL & 7 & & & WILSON & 62 & BADGES & 1 & GATSBY & 1 & & \\
\hline PRUNES & 1 & & & PACKET & 3 & PARTLY & 49 & INCOME & 109 & & \\
\hline
\end{tabular}

WOUNDS 8

WATSON 45

Mean Phoneme Length

$\begin{array}{rrrr}5.20 & 5.00 & 5.50 & 5.88\end{array}$

*Some dictionaries report that the $L$ in FolKsy is silent. The word was included in the present set because its $L$ seemed pronounceable to the present author. To confirm this, in informal tests, about 80 Ohio State students were shown the word and asked to pronounce it; over $90 \%$ said that they pronounced the $\mathrm{L}$. 
APPENDIX C

Set 3. Higher Frequency Words (Frequency of Occurrence; KuCera \& Francis, 1967)

by Number of Syllables

\begin{tabular}{|c|c|c|c|c|c|}
\hline \multicolumn{2}{|c|}{1} & \multicolumn{2}{|c|}{2} & \multicolumn{2}{|c|}{3} \\
\hline Word & Freq. & Word & Freq. & Word & Freq. \\
\hline THINGS & 368 & NUMBER & 472 & UNITED & 482 \\
\hline CHANGE & 240 & WANTED & 226 & POLICY & 222 \\
\hline FRENCH & 139 & DIRECT & 129 & SOVIET & 129 \\
\hline LENGTH & 116 & HARDLY & 106 & EASILY & 106 \\
\hline BRIGHT & 87 & ACTIVE & 88 & POETRY & 88 \\
\hline RIGHTS & 77 & PERMIT & 77 & EDITOR & 77 \\
\hline STRUCK & 59 & PALMER & 56 & AGENCY & 56 \\
\hline BOUGHT & 56 & SYMBOL & 54 & UNABLE & 54 \\
\hline FLIGHT & 46 & PANELS & 46 & АТОМіс & 46 \\
\hline SWITCH & 43 & LAWYER & 43 & OXYGEN & 43 \\
\hline GLANCE & 40 & FINGER & 40 & VISUAL & 40 \\
\hline THROWN & 40 & RANDOM & 40 & COMEDY & 39 \\
\hline THANKS & 37 & BELONG & 37 & IMAGES & 37 \\
\hline BRANCH & 33 & PENCIL & 34 & OPENLY & 34 \\
\hline PRINCE & 33 & MATURE & 31 & POETIC & 31 \\
\hline WARMTH & 28 & GENTLY & 31 & STUDIO & 31 \\
\hline FRAMES & 26 & UPWARD & 27 & INJURY & 27 \\
\hline WEALTH & 22 & NOVELS & 22 & UNEASY & 22 \\
\hline THEIRS & 21 & HABITS & 21 & HEROIC & 21 \\
\hline SCARED & 21 & PLANET & 21 & LINEAR & 21 \\
\hline TRENDS & 21 & TAYLOR & 21 & MELODY & 21 \\
\hline BLONDE & 20 & HOTELS & 20 & ANYHOW & 20 \\
\hline LACKED & 19 & NEATLY & 19 & MEXICO & 19 \\
\hline BRAINS & 18 & CANDLE & 18 & DENIAL & 18 \\
\hline PRAISE & 17 & PASTOR & 17 & DEPUTY & 17 \\
\hline FRINGE & 16 & FABRIC & 15 & HELIUM & 15 \\
\hline PRIEST & 16 & LYRICS & 15 & ISRAEL & 15 \\
\hline THREAD & 15 & RENTAL & 15 & MISERY & 15 \\
\hline SCREAM & 13 & ETHNIC & 13 & NUCLEI & 13 \\
\hline BREAKS & 12 & CLERGY & 12 & CAVITY & 12 \\
\hline \multicolumn{6}{|c|}{ Mean Phoneme Length } \\
\hline \multicolumn{2}{|c|}{4.60} & \multicolumn{2}{|c|}{5.57} & \multicolumn{2}{|c|}{5.97} \\
\hline
\end{tabular}

APPENDIX D

Set 4. Lower Frequency Words (Frequency of Occurrence; Kucera \& Francis, 1967) by Number of Syllables

\begin{tabular}{|c|c|c|c|c|c|}
\hline \multicolumn{2}{|c|}{1} & \multicolumn{2}{|c|}{2} & \multicolumn{2}{|c|}{3} \\
\hline Word & Freq. & Word & Freq. & Word & Freq \\
\hline CROWDS & 12 & LASTED & 12 & PURITY & 12 \\
\hline QUAINT & 12 & SECANT & 12 & SODIUM & 12 \\
\hline BRONZE & 11 & GRIMLY & 11 & BURIAL & 11 \\
\hline CHARTS & 9 & INDUCE & 9 & ALUMNI & 9 \\
\hline LOUNGE & 9 & UNPAID & 9 & RADIUS & 9 \\
\hline PREACH & 8 & DANISH & 8 & ANGELO & 8 \\
\hline TRICKS & 8 & GIBSON & 8 & BUSILY & 8 \\
\hline BOUNCE & 8 & RELISH & 8 & GAIETY & 8 \\
\hline SPRUNG & 8 & STORMY & 8 & NOTIFY & 8 \\
\hline BRAKES & 8 & WESTON & 8 & OVERLY & 8 \\
\hline BUILDS & 7 & CRADLE & 7 & BODILY & 7 \\
\hline CLERKS & 7 & BRUTAL & 7 & EXOTIC & 7 \\
\hline CURVED & 7 & INSULT & 7 & MYRIAD & 7 \\
\hline STRAND & 7 & LINGER & 7 & OLIVER & 7 \\
\hline CORPSE & 7 & DEMONS & 7 & SERIAL & 7 \\
\hline WORLDS & 7 & NICKEL & 7 & SOPHIA & 7 \\
\hline YIELDS & 7 & PAXTON & 7 & VANITY & 7 \\
\hline GRAPES & 7 & RECKON & 7 & VIOLET & 7 \\
\hline STREWN & 6 & FUTILE & 6 & FINALE & 6 \\
\hline FLOWED & 6 & TRIBAL & 6 & MODIFY & 6 \\
\hline SHRIEK & 5 & EMBARK & 5 & LEGACY & 5 \\
\hline HOARSE & 5 & LYFORD & 5 & LIVERY & 5 \\
\hline PLANKS & 5 & BANTER & 5 & VERIFY & 5 \\
\hline SQUIRE & 5 & SOFTER & 5 & VIABLE & 5 \\
\hline CHROME & 4 & BAKING & 4 & ARISEN & 4 \\
\hline BRANDS & 4 & DICTUM & 4 & EXODUS & 4 \\
\hline STROVE & 4 & COMPEL & 4 & FIASCO & 4 \\
\hline THORPE & 4 & CHAVEZ & 4 & ENIGMA & 4 \\
\hline SLUDGE & 4 & IMPART & 4 & ORIENT & 4 \\
\hline STARCH & 4 & GODWIN & 4 & PARODY & 4 \\
\hline
\end{tabular}

Mean Phoneme Length

(Manuscript received October 23, 1991;

revision accepted for publication April 6, 1992.) 